ANATOLIAN

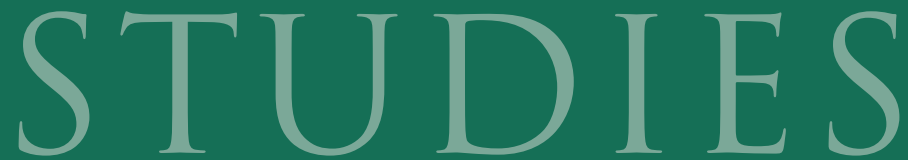

Journal of the British Institute at Ankara (6)

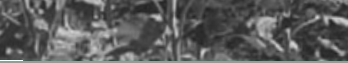




\section{THE BRITISH INSTITUTE AT ANKARA}

The British Institute at Ankara (BIAA) supports, enables and encourages research in Turkey and the Black Sea region in a wide range of fields including archaeology, ancient and modern history, heritage management, social sciences and contemporary issues in public policy and political sciences. Founded in 1948, the BIAA was incorporated in the 1956 cultural agreement between the Republic of Turkey and the United Kingdom. The BIAA is one of the British International Research Institutes (BIRI). It has offices in Ankara and London, and a dedicated staff of experts from a wide variety of academic and cultural backgrounds.

The Institute's premises in Ankara are maintained by a small administrative and research staff, and provide a research centre for visiting scholars and students. The centre houses a library of over 65,000 volumes, research collections of botanical, faunal, epigraphic and pottery material, together with collections of maps, photographs and fieldwork archives, and a laboratory and computer services.

The Institute uses its financial, practical and administrative resources to conduct high-quality research. The overall focus of the research sponsored by the BIAA is on history, society and culture from prehistory to the present day, with particular attention to the ideas of Turkey as a crossroads, Turkey's interactions with the Black Sea region and its other neighbours, and Turkey as a distinctive creative and cultural hub in global and neighbourhood perspectives. The BIAA supports a number of projects grouped within its Strategic Research Initiatives, which reflect current research concerns in the international and UK academic communities. These are: Cultural heritage, society and economy in Turkey; Migration, minorities and regional identities; Interconnections of peace and conflict: culture, politics and institutions in national, regional and international perspectives; Anglo-Turkish relations in the 20th century; Climate change and the environment; Habitat and settlement in prehistoric, historical and contemporary perspectives; Legacy data: using the past for the future. The Institute also offers a range of grants, scholarships and fellowships to support undergraduate to post-doctoral research.
The BIAA is an organisation that welcomes new members. As its role in Turkey develops and extends to new disciplines, it hopes to attract the support of academics, students and others who have diverse interests in Turkey and the Black Sea region. The annual subscription (discounted for students and the unwaged) entitles members to: copies of the annual journal, Anatolian Studies, the annual magazine, Heritage Turkey, and newsletters; a 20\% discount on BIAA monographs published by Oxbow Books and a 30\% discount on books relating to Turkey published by I.B. Tauris; use of the Institute's facilities in Ankara, including the hostel, research library of 65,000 volumes, laboratories, computer services and extensive research and archival collections; attend all BIAA lectures, events and receptions held in London or elsewhere in the UK; nominate candidates for and stand for election to the Institute's Council; and discounts on Turkish holidays organised by travel firms closely associated with the BIAA.

Membership including subscription to Anatolian Studies costs $£ 50$ per year (or $£ 25$ for students and unwaged).

To join the Institute or for further information about its work, please contact us at:

British Institute at Ankara

10 Carlton House Terrace

London SW1Y 5AH

Email: biaa@britac.ac.uk

Web site: biaa.ac.uk

Copies of Anatolian Studies volume 62 onwards are available from Cambridge University Press. Please see inside front cover for contact details. 


\section{ANATOLIAN}

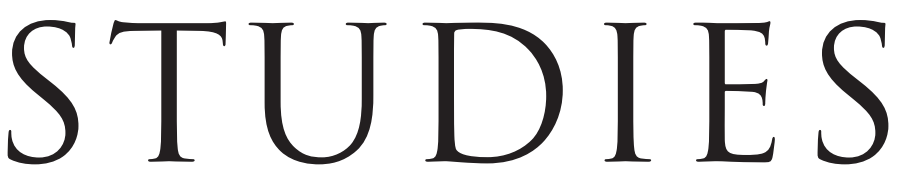

Journal of the British Institute at Ankara

\section{ARTICLES}

1 A comparative study of the Initial Neolithic chipped-stone assemblages of Ulucak and Uğurlu Denis Guilbeau, Nurcan Kayacan, Çiler Altınbilek-Algül, Burçin Erdoğu and Özlem Çevik

21 Stability and change at Çadır Höyük in central Anatolia: a case of Late Chalcolithic globalisation? Sharon R. Steadman, Gregory McMahon, Benjamin S. Arbuckle, Madelynn von Baeyer, Alexia Smith, Burcu Yıldırım, Laurel D. Hackley, Stephanie Selover and Stefano Spagni

59 Reassessing western and central Anatolian Early Bronze Age sealing practices: a case from Boz Höyük (Afyon)

Michele Massa and Yusuf Tuna

77 An insight into Old Hittite metallurgy: alloying practices at Hüseyindede (Çorum, Turkey) Gonca Dardeniz, I. Tunç Sipahi and Tayfun Yıldırım

95 The dualistic nature of a Red Lustrous Wheelmade bowl from Boğazköy with a depiction of a victorious armed warrior

Ekin Kozal

109 The collapse of empire at Gordion in the transition from the Achaemenid to the Hellenistic world Elspeth R.M. Dusinberre

133 Leader-gods and pro poleos priests: Leto, Apollo, Zeus and the imperial cult at Oinoanda N.P. Milner

155 The sanctuary of Zeus Sarnendenos and the cult of Zeus in northeastern Phrygia Hale Güney

175 The development of the Church of St Mary at Ephesos from late antiquity to the Dark Ages Nikolaos Karydis 